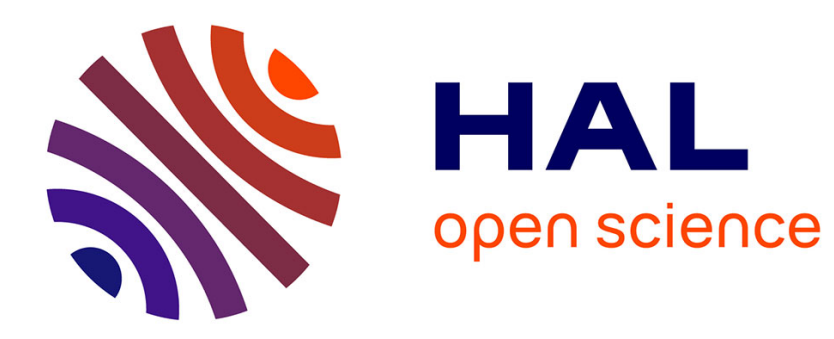

\title{
Rheological behavior of crosslinked waxy maize starch-kappa-carrageenan mixtures
}

\author{
A. Tecante, J.L. Doublier
}

\section{To cite this version:}

A. Tecante, J.L. Doublier. Rheological behavior of crosslinked waxy maize starch-kappa-carrageenan mixtures. 5. European Rheology Conference, Sep 1998, Portoroz, Slovenia. hal-02768137

\section{HAL Id: hal-02768137 \\ https://hal.inrae.fr/hal-02768137}

Submitted on 4 Jun 2020

HAL is a multi-disciplinary open access archive for the deposit and dissemination of scientific research documents, whether they are published or not. The documents may come from teaching and research institutions in France or abroad, or from public or private research centers.
L'archive ouverte pluridisciplinaire HAL, est destinée au dépôt et à la diffusion de documents scientifiques de niveau recherche, publiés ou non, émanant des établissements d'enseignement et de recherche français ou étrangers, des laboratoires publics ou privés. 


\section{Progress and Trends in Rheology V}

Proceedings of the Fifth European Rheology Conference

Portorož, Slovenia, September 6-11, 1998

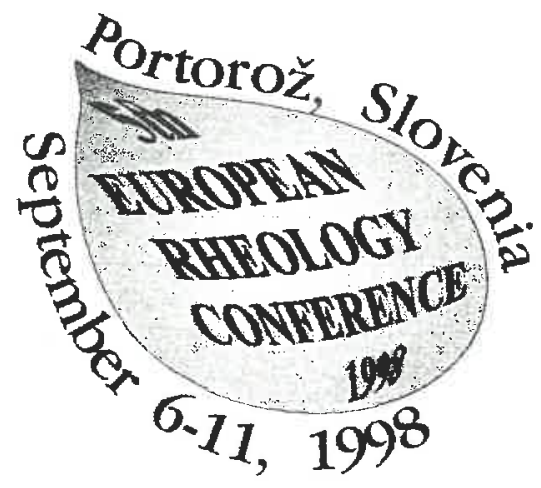

Editor

I. Emri

Center for Experimental Mechanics

University of Ljubljana, Ljubljana, Slovenia

Technical Co-Editor

\section{R. Cvelbar}

Center for Experimental Mechanics

University of Ljubljana, Ljubljana, Slovenia

$$
\begin{aligned}
& \text { ISBN }=3.7985 .1128-4 . \\
& 1998 .
\end{aligned}
$$


Die Deutsche Bibliothek CIP-Einheitsaufnahme

Progress and trends in rheology $V_{\text {.: }}$ proceedings of the Fifth European Rheology Conference, Portorož, Slovenia, September 6 - 11, 1998 / ed. I. Emri.

Technical co-ed. R. Cvelbar. Darmstadt : Steinkopff, 1998

ISBN 3-7985-1 128-4
This work is subject to copyright. All rights are reserved, whether the whole or part of the material is concerned, specifically those rights of translation, reprinting, reuse of illustrations, recitation, broadcasting, reproduction on microfilms or in other ways, and storage in data banks. Duplication of this publication or parts thereof is only permitted under the provisions of the German Copyright Law of September 9, 1965, in its version of June 24,1985 , and a copyright fee must always be paid. Violations fall under the prosecution act of the German Copyright Law.

The use of registered names, trademarks, etc. in this publication does not imply, even in the absence of specific statement, that such names are exempt from the relevant protective laws and regulations and therefore free for general use.
(C)1998

by Dr. Dietrich Steinkopff Verlag GmbH \& Co. KG, Darmstadt

Chemisty Editor: Dr. Maria

Magdalene Nabbe;

Production: Holger Frey

Printed in Germany by Druckhaus Beltz, Hemsbach 


\section{A. TECANTE ${ }^{1}$ and J.L. DOUBLIER}

Inventaire

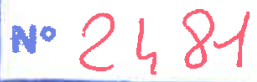

Institut National de la Recherche Agronomique, Rue de la Géraudière, BP 71627-44316, Nantes, France. ${ }^{1}$ Permanent address: Depto. Alimentos y Biotecnología, FQ-“E”, UNAM, México, D.F., 04510, México.

\section{INTRODUCTION}

The aim of this study is to get a better understanding of the rheological behavior of starch-hydrocolloid mixtures under gelling and non-gelling conditions of the latter. Crosslinked waxy maize starch (CWMS) was used because it is free of amylose and crosslinking avoids granule rupture. Hence, swelled granules are dispersed in a phase containing essentially the hydrocolloid. Application of mixtures with $\kappa$-carrageenan $(\kappa \mathrm{C})$ in the food industry provided further motivation to this work.

\section{METHODS}

\section{$2.1 \quad$ Materials}

The CWMS sample $\left(\right.$ Clearam $\left.^{\circledR} \mathrm{CH} 10\right)$ was an adipate/acetate starch obtained from Roquette Frères. $\mathrm{KC}$ was provided by SBI (France) and was used without further treatment. Analytical grade $\mathrm{KCl}$ (Merck) and deionized water were used "throughout.

\subsection{Pasting procedure}

All starch slurries were pasted in a Brabender viscograph-E at a bowl speed of $75 \mathrm{rpm}$ following the thermal treatment shown in Figure 1. The apparatus was used only as a cooker and to monitor consistency changes during pasting. Dryweight concentrations were: CWMS $4 \%, \mathrm{\kappa C} 0.5 \%$. in some slurries $20 \mathrm{mM} \mathrm{KCl}$ was added to induce $\mathrm{C}$ gelation upon cooling.

\subsection{Rheological measurements}

Steady shear tests were carried out at $60{ }^{\circ} \mathrm{C}$ with a rotational viscometer (Rheomat 120 ) in a coaxial-cylinders fixture (diameters: bob $=46 \mathrm{~mm}$, cup $=49 \mathrm{~mm}$, height $78 \mathrm{~mm}$ ). Two consecutive updown shear scans from 0 to $660 \mathrm{~s}^{-1}$ followed by a logarithmic descent from 660 to $0.1 \mathrm{~s}^{-1}$ were applied. Low amplitude (0.04) oscillatory shear was carried out at $60^{\circ} \mathrm{C}$ and $25^{\circ} \mathrm{C}$ in a controlledstress rheometer (Carrimed CS50) using either the cone/plate (diam. $6 \mathrm{~cm}$, angle $4^{\circ}$ ) or grooved parallel plates (diam. $4 \mathrm{~cm}$, gap $1 \mathrm{~mm}$ ) geometries. Gap adjustment considered thermal expansion. The fixture rim was covered with paraffin oil to prevent evaporation.

\subsection{Solubility-swelling determination}

The degree of granule swelling and starch solubility were determined according to previously described procedures (Doublier 1987).

\section{RESULTS AND DISCUSSION}

In the following discussion $\mathrm{A}, \mathrm{B}$ and $\mathrm{C}$ designate, respectively, CWMS, CWMS/KC and $\mathrm{CWMS} / \mathrm{KC} / \mathrm{KCl}$. Figure 1 shows the differences in consistency. The earlier peak in $\mathrm{C}$ is due to $\mathrm{KC}$ solubilization. Swelling start-up occurred slightly earlier $\left(\sim 64{ }^{\circ} \mathrm{C}\right)$ in $\mathrm{B}$ than in $\mathrm{A}$ and $\mathrm{C}\left(\sim 66^{\circ} \mathrm{C}\right)$. All pastes displayed a rapid swelling followed by a smooth transition to an essentially constant zone during the holding period which indicates good thermal stability.

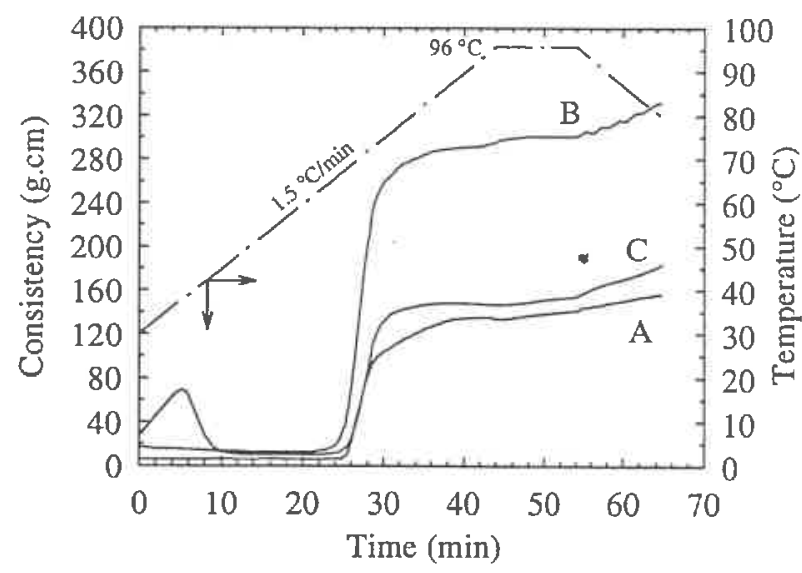

Figure 1. Brabender consistency of starch pastes.

The flow properties of hot pastes are shown in Figure 2. The first up-down scan (continuous line) reveals an anti-thixotropic behavior with $\mathrm{C}$ displaying the greatest hysteresis. Timedependency essentially disappeared after 
continuous shearing as shown by the second scan (dotted line) which was always superimposed to the descending curve of the first one. Shearthinning behavior is clear; nevertheless, flow curves could not be described by the power law model over all the shear rate range.

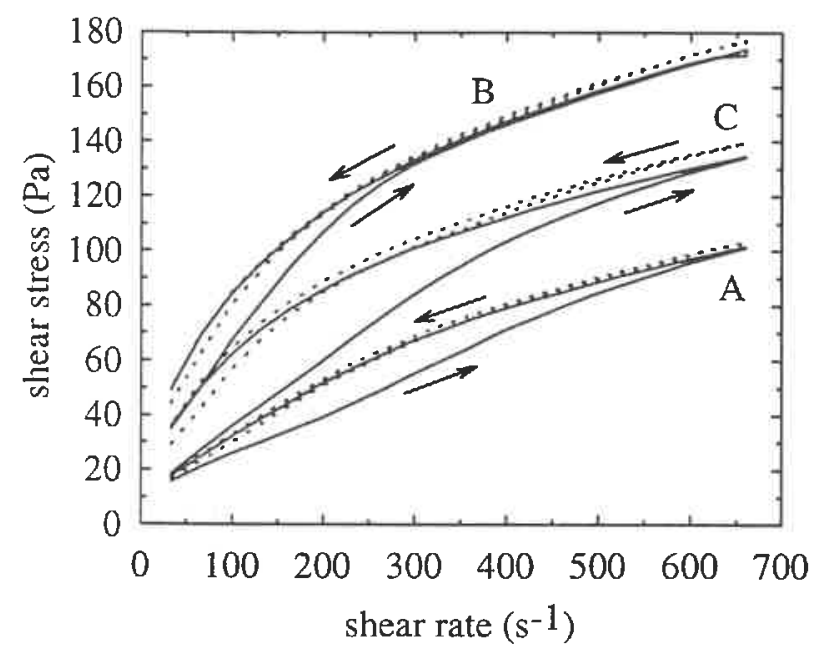

Figure 2. Flow curves of starch pastes at $60^{\circ} \mathrm{C}$.

The viscoelastic properties of hot pastes are shown in Figure 3. None of them was a selfstanding gel, yet $\mathrm{A}$ and $\mathrm{B}$ exhibited apparently a solid-like behavior with $G^{\prime}>G^{\prime \prime}$ and

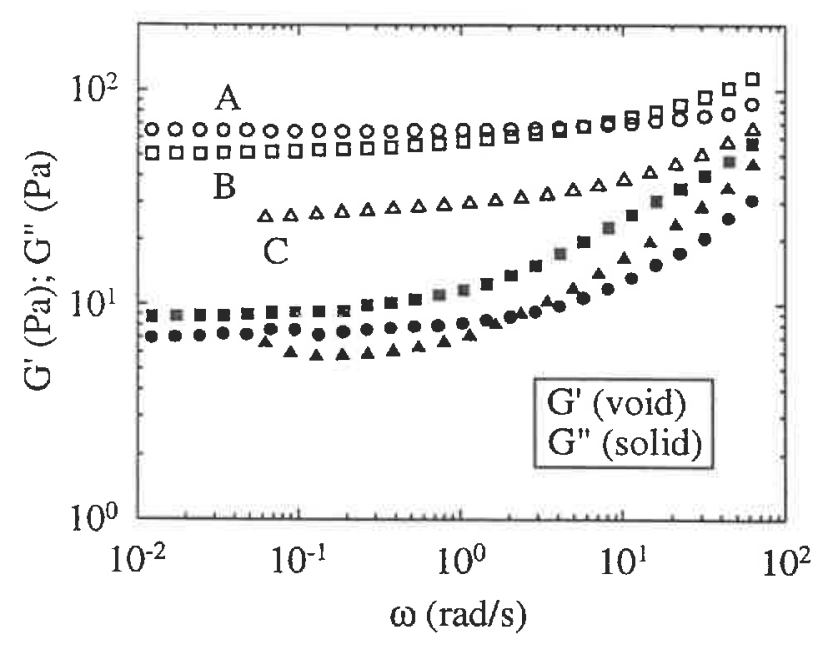

Figure 3. Dynamic moduli of pastes at $60^{\circ} \mathrm{C}$.

both independent of $\omega$ below 1 and $0.2 \mathrm{rad} / \mathrm{s}$, respectively. In $\mathrm{C}$, lower and more frequencydependent moduli were observed. Paste A had the lowest loss angles $(\tan \delta \approx 0.1$ at $\omega<1 \mathrm{rad} / \mathrm{s})$, while $B$ and $C$ displayed higher and more frequency-dependent loss angles.
Figure 4 shows the mechanical spectra of cooled pastes. As expected, $\mathrm{C}$ was a self-stanüing gel with a typical spectrum; G' $>G^{\prime \prime}$ and both independent of $\omega$. In fact, $\tan \delta<0.02$ showing an essentially elastic response. $\mathrm{A}$ and $\mathrm{B}$ exhibited a behavior similar to that at $60{ }^{\circ} \mathrm{C}$ with slightly higher moduli.

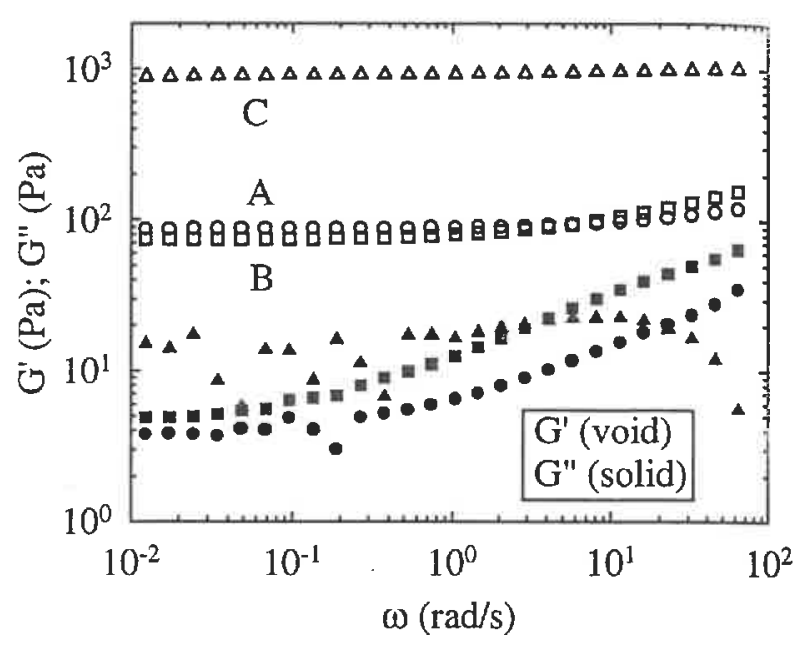

Figure 4. Dynamic moduli of systems at $25^{\circ} \mathrm{C}$.

Starch solubility was low $(\sim 2 \%)$ and swelling was $25.9,27.3$ and $29.3 \mathrm{~g} / \mathrm{g}$ for A, C and $B$, respectively, which resulted in starch volume fractions very near to unity. At such value a closepacking of swelled granules can be present (Bagley and Christianson, 1982) leaving a reduced volume to the fluid phase. Therefore, our systems were highly charged and this may explain the initial antithixotropic behavior the extent of which depended on the viscosity of the fluid phase. On the other hand, at $60^{\circ} \mathrm{C}$ and $25^{\circ} \mathrm{C}$ (except $\mathrm{C}$ ), the increasing dependence of moduli with frequency can be attributed to the response of the continuous phase which is to some extent overwhelmed by that of starch particles. Systems behaved as highly concentrated suspensions of starch particles in water (A at $60{ }^{\circ} \mathrm{C}$ and $25{ }^{\circ} \mathrm{C}$ ) and in a macromolecular solution (B at $60{ }^{\circ} \mathrm{C}$ and $25^{\circ} \mathrm{C}$ and $\mathrm{C}$ at $60^{\circ} \mathrm{C}$ ), and as a composite gel of swollen particles embedded in a macromolecular network (C at $25^{\circ} \mathrm{C}$ ).

\section{REFERENCES}

Bagley EB, Christianson DD (1982) J. Texture Stud., 13: 115126.

Doublier JL (1987) J. Cereal Sci., 5:247-262. 